\title{
Chemical Composition, Antimicrobial Activity, and Antioxidant Activity of Ocotea minarum (Nees \& Mart.) Mez.
}

\author{
Allan Belarmino Rodrigues, ${ }^{1}$ Adriana Araújo de Almeida-Apolonio (D), \\ Tamaeh Monteiro Alfredo, ${ }^{3}$ Fabiana Gomes da Silva Dantas $\mathbb{D}^{3},{ }^{3}$ Jaqueline Ferreira Campos, ${ }^{4}$ \\ Claudia Andrea Lima Cardoso, ${ }^{5}$ Kely de Picoli Souza ${ }^{(D)}{ }^{4}$ \\ and Kelly Mari Pires de Oliveira $\mathbb{D i D}^{1,4}$
}

\author{
${ }^{1}$ Faculty of Exact Sciences and Technology, Federal University of Grande Dourados, Dourados, MS 79804-970, Brazil \\ ${ }^{2}$ Faculty of Medicine, Federal University of Mato Grosso do Sul, Campo Grande, MS 79070-900, Brazil \\ ${ }^{3}$ Faculty of Health Sciences, Federal University of Grande Dourados, Dourados, MS 79804-970, Brazil \\ ${ }^{4}$ Faculty of Biological and Environmental Science, Federal University of Grande Dourados, Dourados, MS 79804-970, Brazil \\ ${ }^{5}$ Course of Chemistry, State University of Mato Grosso do Sul, Dourados, MS 79804-970, Brazil
}

Correspondence should be addressed to Kelly Mari Pires de Oliveira; kellyoliveira@ufgd.edu.br

Received 15 December 2018; Accepted 17 February 2019; Published 28 April 2019

Academic Editor: Grzegorz Bartosz

Copyright (c) 2019 Allan Belarmino Rodrigues et al. This is an open access article distributed under the Creative Commons Attribution License, which permits unrestricted use, distribution, and reproduction in any medium, provided the original work is properly cited.

\begin{abstract}
Ocotea minarum is a native plant from Brazil, popularly known as "canelinha" or "canela vassoura." The objective of this study was to investigate the chemical composition of the extracts of the bark and the leaves of O. minarum and to evaluate its antimicrobial and antioxidant activities. The phenolic compounds, flavonoids and tanins, were quantified with the reagents Folin-Ciocalteu, aluminium chloride, and vanillin. The chemical profile was performed by HPLC-DAD. The minimum inhibitory concentration was evaluated by the microdilution in a broth method. The antioxidant activity was measured by the capture of free radicals 2,2-diphenyl-1-picrylhydrazyl and 2,2'-azinobis(3-ethylbenzothiazoline-6-sulfonic acid). In addition, protection against oxidative hemolysis and generation of malondialdehyde were evaluated in human erythrocytes. The composition of the extracts included the caffeic acid, p-coumaric acid, and rosmarinic acid, besides the flavonoids quercetin and luteolin. The EEL showed bacteriostatic action of $1000 \mu \mathrm{g} / \mathrm{mL}$ for all evaluated Salmonella Typhimurium, Salmonella Enteritidis, Pseudomonas aeruginosa, and Proteus mirabilis, and the EHEB had a moderate antifungal action against Candida krusei and Cryptococcus gattii $(250 \mu \mathrm{g} / \mathrm{mL}) . \mathrm{IC}_{50}$ values of 8.19 (EEL) and $4.51 \mu \mathrm{g} / \mathrm{mL}$ (EEB) in the assay with DPPH and $6.25(\mathrm{EEL})$ and $2.87 \mu \mathrm{g} / \mathrm{mL}$ (EEB) in the assay with ABTS were obtained. Up to the 3rd hour of oxidative hemolysis testing induced by AAPH, the EEB and EEL had a protective action, reducing the malondialdehyde. In conclusion, the data indicate that the O. minarum extracts can be evaluated as bioactive supplies for the development of new drugs for the prevention and treatment of diseases related to oxidative stress and microbial infections.
\end{abstract}

\section{Introduction}

The use of medicinal plants as raw material to develop products for therapeutic purposes is common. It has been estimated that from the 60,000 species discovered, the biological potential of 800 species has been evaluated $[1,2]$. It is known that plants with secondary metabolites, such as alkaloids, coumarins, tannins, terpenes, and flavonoids, are sources of several bioactive compounds that are beneficial to human health [3].

These compounds are described as having various biological activities, including antimicrobial action. Microbial infections are growing at an alarming level $[4,5]$ owing to the ability of bacteria and yeasts to acquire and transmit 
genetic resistance material, leading to the constant evolution of multidrug-resistant microorganisms that threaten public health [6-8]. In this milieu, medicinal plants are receiving special attention for the development of new antimicrobial agents due to their therapeutic activity, low toxicity, and economic viability when compared with those of traditional allopathic compounds $[9,10]$.

Another problem that affects public health is the degeneration of tissues and biomolecules caused by the imbalance of oxidative substances and antioxidants in the body, leading to oxidative stress. Oxidative stress is an important factor that triggers cardiovascular and neurodegenerative diseases, inflammation, diabetes, and premature aging, among others $[11,12]$. An approach to reduce this condition is the use of antioxidant substances that can act in the neutralization or even in the capture of reactive species, thus, minimizing oxidative tissue damage $[13,14]$.

Compounds such as butylated hydroxyanisole (BHA) and butylated hydroxytoluene (BHT) are the widely used synthetic antioxidants, but are questioned due to their nutritional value and possible mutagenic, carcinogenic, and toxic effects, including hepatotoxicity [15-17]. Generally, natural antioxidants have low toxicity and are easily biodegradable, making them an effective alternative to reduce oxidative stress $[18,19]$.

Additionally, tropical and subtropical plant species are of increasing research interest, as they have diverse properties, such as potent antimicrobial and antioxidant activities $[13,20]$. In this context, the members of the genus Ocotea stand out, which are among the most expressive of the family Lauraceae. Among these, approximately 300-400 species are found in the tropical and subtropical regions $[21,22]$, and it has been estimated that $120-160$ species are found in Brazil [23] dispersed in the biomes of Atlantic Forest and Cerrado [24]. Studies on species of the genus Ocotea have demonstrated several biological activities, such as antimicrobial [25-29], antioxidant [25, 26, 29-32], antiinflammatory [30, 33], and antiprotozoal activities [34].

Among the genus Ocotea, the species Ocotea minarum (Nees \& Mart) Mez., a medium-sized tree, popularly known as "canelinha" or "canela vassoura" [35], contains aporphine alkaloids [36], indole alkaloids, coumarins, flavonoids, biflavonoids, bis-lignans, alkyl benzene, steroids, sesquiterpenes, nor-sesquiterpenes, and terpene lactone [37]. However, studies on the antibacterial and antioxidant properties of O. minarum are limited. Thus, the objective of the present study was to (1) determine the phytochemical profile, (2) evaluate the antifungal activity, and (3) for the first time, evaluate the antibacterial activity and antioxidant potential of $O$. minarum bark and leaf extracts.

\section{Materials and Methods}

2.1. Plant Material. The stem bark and leaves of $O$. minarum were collected from the Mata dos Macacos farm $\left(22^{\circ} 08^{\prime}\right.$ $\left.47.2^{\prime \prime} \mathrm{S}, 54^{\circ} 54^{\prime} 54.1^{\prime \prime} \mathrm{W}\right)$ in the city of Dourados, Mato Grosso do Sul, Brazil. The samples were identified by Prof. Dr. Zefa Valdivia Pereira and deposited in the Herbarium of the Faculty of Biological and Environmental Sciences
(FCBA) in the Federal University of Grande Dourados (UFGD) under the registered number 5275 DDMS.

2.2. Preparation of Extracts. The barks (246.80 g) and leaves $(237.28 \mathrm{~g})$ were sterilized and dried in a laminar flow cabinet at $40^{\circ} \mathrm{C}$ for 10 and 6 days, respectively. Subsequently, the samples were pulverized using a cutting mill. The sample was extracted with $800 \mathrm{~mL}$ of $80 \%$ ethyl alcohol at ambient temperature with regular shaking at every $24 \mathrm{~h}$. After $72 \mathrm{~h}$, the mixture was filtered using a filter paper $(0.45 \mu \mathrm{m})$, rotoevaporated at $35^{\circ} \mathrm{C}$ and lyophilized to obtain the ethanolic extract of barks (EEB) and leaves (EEL) of O. minarum.

Solvents with increasing polarity (hexane and ethyl acetate) were used to prepare the liquid-liquid partitions to obtain hydroalcoholic extract (HYEB and HYEF), hexane extract (HEEB and HEEL), and ethyl acetate extract (EAEB and EAEL) from the barks and leaves of $O$. minarum, respectively [38].

2.3. Determination of Phenolic Compounds. The content of phenolic compounds was determined as described by Djeridane et al. [39]. To obtain $100 \mu \mathrm{L}$ of the EEB and EEL at a concentration of $100 \mu \mathrm{g} / \mathrm{mL}, 500 \mu \mathrm{L}$ of FolinCiocalteu reagent and $1 \mathrm{~mL}$ of distilled water were added and incubated at ambient temperature for $1 \mathrm{~min}$. Subsequently, $1.5 \mathrm{~mL}$ of $20 \%$ sodium carbonate was added to this solution and incubated for $2 \mathrm{~h}$ in the dark at ambient temperature. The absorbance was read at $760 \mathrm{~nm}$. The concentration of phenolic compounds was calculated by preparing an analytical curve using gallic acid as standard at concentrations of $100,200,300,400,500,600,700,800,900$, and $1000 \mu \mathrm{g} / \mathrm{mL}$. With the data, the linear regression was developed and the equation of line was obtained, with a linear correlation coefficient of $R^{2}=0.997$, slope $a=-0.018$, and linear coefficient $b=0.0016$. The results are expressed as milligrams of gallic acid equivalent (mg/GAE) per gram of extract. All analyses were performed in triplicate.

2.4. Determination of Flavonoids. The content of flavonoids was determined by the method described by Lin and Tang [40]. Five hundred microliters of EEB and EEL at a concentration of $100 \mu \mathrm{g} / \mathrm{mL}$ was added to $1.5 \mathrm{~mL}$ of $95 \%$ ethyl alcohol, $0.1 \mathrm{~mL}$ of $10 \%$ aluminum chloride hexahydrate $\left(\mathrm{AlCl}_{3}\right)$, $0.1 \mathrm{~mL}$ of $1 \mathrm{M}$ potassium acetate $\left(\mathrm{CH}_{3} \mathrm{COOK}\right)$, and $2.8 \mathrm{~mL}$ of deionized water. The reaction mixture was incubated at ambient temperature for $40 \mathrm{~min}$, and the absorbance was read using a spectrophotometer at a wavelength of $415 \mathrm{~nm}$. To determine the concentration of flavonoids, an analytical curve was prepared using quercetin as standard at concentrations of $10,20,30,40$, and $50 \mu \mathrm{g} / \mathrm{mL}$, and the respective absorbance was read. With the obtained data, the linear regression and the equation of the line with $R^{2}=0.999, a=0.0019$, and $b=0.0105$ were obtained. The results are expressed as milligrams of quercetin equivalent $(\mathrm{mg} / \mathrm{QE})$ per gram of extract. All analyses were performed in triplicate.

2.5. Determination of Tannins. The tannins were quantified by the vanillin reaction according to the method of Broadhurst and Jones [41], adapted by Agostini-Costa et al. [42]. Five milliliters of freshly prepared vanillin reagent (vanillin- 
HCL-methanol, $4: 10: 86)$ was taken in a test tube and $1 \mathrm{~mL}$ of EEB or EEL, at a concentration of $100 \mu \mathrm{g} / \mathrm{mL}$, was added and agitated for $30 \mathrm{~s}$. The reaction mixture was undisturbed for $15 \mathrm{~min}$, and the absorbance was read at $490 \mathrm{~nm}$. The quantification was done using an external calibration curve with catechin as standard, at concentrations of 2.5, 5, 10, 20,30 , and $40 \mu \mathrm{g} / \mathrm{mL}$, and their absorbance was read, to obtain the equation of line with $R^{2}=0.998, a=0.006$, and $b=0.0018$. The results are expressed as milligrams of catechin equivalent (mg/CAE) per gram of extract. All analyses were performed in triplicate.

2.6. High-Performance Liquid Chromatography with DiodeArray Detector (DAD). The extracts were analyzed by high-performance liquid chromatography (HPLC) using a Shimadzu model, equipped with the C18 Phenomenex Gemini column $(25 \mathrm{~cm} \times 4.6 \mathrm{~mm} \times 5 \mu \mathrm{m})$. The flow rate was $1 \mathrm{~mL} / \mathrm{min}$, with scans between 200 and $800 \mathrm{~nm}$, and the injection volume was $10 \mu \mathrm{L}$. The mobile phase was as follows: $6 \%$ acetic acid in water, $2 \mathrm{mM}$ sodium acetate (eluent A), and acetonitrile (eluent B). The gradient used was as follows: $0 \mathrm{~min} 5 \% \mathrm{~B}, 45 \mathrm{~min} 15 \% \mathrm{~B}, 55 \mathrm{~min} 30 \%$ B, $60 \mathrm{~min} 50 \% \mathrm{~B}$, and $65 \mathrm{~min} 100 \% \mathrm{~B}$ [43].

\subsection{Antimicrobial Activity}

2.7.1. Microorganisms for Antimicrobial Testing. The microorganisms were obtained from the American Type Culture Collection (ATCC, Rockville, MD, USA). The microorganisms included the following yeasts: Candida albicans (90028), Candida glabrata (2001), Candida krusei (6558), Candida tropicalis (750), Candida parapsilosis (22019), Candida dubliniensis (MYA-646), Cryptococcus gattii (56990), Cryptococcus neoformans (32045), Rhodotorula glutinis (2527), and Rhodotorula mucilaginosa (64684). Grampositive bacteria included Staphylococcus aureus (25923), Staphylococcus epidermidis (12228), and Bacillus cereus (11778). Gram-negative bacteria included Salmonella Typhimurium (14028), Salmonella Enteritidis (13076), Pseudomonas aeruginosa (27853), and Proteus mirabilis (35659).

To prepare the inoculum, the microorganisms were suspended in sterile saline solution $(0.9 \% \mathrm{NaCl})$ and adjusted using a spectrophotometer (Quimis, Diadema, SP, Brazil). $90 \%( \pm 2)$ transmittance at $530 \mathrm{~nm}$ corresponding to a suspension of $2.5 \times 10^{6} \mathrm{UFC} / \mathrm{mL}$ concentration, for yeasts, and an absorbance of $0.110( \pm 0.005)$ at $625 \mathrm{~nm}$ corresponding to a concentration of $1.5 \times 10^{8} \mathrm{UFC} / \mathrm{mL}$, for bacteria, were used.

2.7.2. Determination of Minimum Inhibitory Concentration (MIC) of the Extract. The susceptibility assay was performed by the broth microdilution technique, according to the guidelines of the Clinical and Laboratory Standards Institute. The standards of document M27-A3 [44] and document M07-A9 [45] with some modifications for the use of plant extracts were used for yeasts and bacteria, respectively.

The EEB, EEL, HYEB, HEEB, EAEB, HYEF, HEEL, and EAEL were dissolved in dimethylsulfoxide (DMSO) and then diluted $(1: 2)$ to concentrations of 1.9 and $1000 \mu \mathrm{g} / \mathrm{mL}$. As a control, $100 \mu \mathrm{L}$ of culture medium and $50 \mu \mathrm{L}$ of extracts were added to the wells of column 1 of a 96-well microplate. The amount of inoculum added to the plates was 10 and $100 \mu \mathrm{L}$ for bacteria and yeasts, respectively. The culture medium used was RPMI-1640 for yeasts and Müller Hinton broth for bacteria. The microplates were incubated at $35^{\circ} \mathrm{C}$ for $48 \mathrm{~h}$ for Candida sp. and $72 \mathrm{~h}$ for Cryptococcus sp. and Rhodotorula sp. and at $37^{\circ} \mathrm{C}$ for $24 \mathrm{~h}$ for the bacteria. Fluconazole was used as a control antifungal agent and ampicillin as a control antibiotic. The experiments were performed in triplicate at three different times.

2.7.3. Minimal Fungicidal Concentration (MFC) and Minimal Bactericidal Concentration (MBC). Aliquots from a microdilution plate (of MIC assay) were transferred to a Petri dish containing Sabouraud Dextrose agar or Müller Hinton agar to the fungicidal and bactericidal activities, respectively. The plates were incubated at $35^{\circ} \mathrm{C}$ for $48 \mathrm{~h}$ for Candida sp. and $72 \mathrm{~h}$ for Cryptococcus sp. and Rhodotorula sp. and at $37^{\circ} \mathrm{C}$ for $24 \mathrm{~h}$ for bacteria. The MFC and MBC were defined as the lowest concentration capable of inhibiting colony growth [46].

\subsection{Antioxidant Activity}

2.8.1. Capture Test of 2,2-Diphenyl-1-picrylhydrazyl (DPPH) Radical. The antioxidant activity of EEB and EEL was evaluated by the method of Sharma et al. [47] using the free radical 2,2-diphenyl-1-picrylhydrazyl (DPPH). Ethanolic solution of DPPH $(0.11 \mathrm{mM}, 1800 \mu \mathrm{L})$ was incubated with $200 \mu \mathrm{L}$ of the positive controls, ascorbic acid, and hydroxybutyltoluene (BHT) or EEB and EEL at concentrations of $0.1-2000 \mu \mathrm{g} / \mathrm{mL}$ in $80 \%$ ethanol. After $30 \mathrm{~min}$ of incubation at ambient temperature (protected from light), the absorbance was read using a spectrophotometer (Quimis, Diadema, SP, Brazil) at $517 \mathrm{~nm}$; the absorbance of each sample was transformed into free radical inhibition percent using formula (1). Three independent experiments were performed in triplicate.

Radical scavenging $(\%)=\frac{(\text { Abs control }- \text { Abs sample })}{\text { Abs control }} \times 100$.

2.8.2. Capture of Free Radical 2,2'-Azinobis(3ethylbenzothiazoline-6-sulfonic Acid) (ABTS). The free radical inhibition capacity of the EEB and EEL was evaluated according to the method described by $\mathrm{Re}$ et al. [48] using 2,2' -azinobis(3-ethylbenzothiazoline-6-sulfonic acid) (ABTS). Ascorbic acid and BHT were used as positive controls. The stock solution of ABTS was prepared using potassium persulfate at $12-16 \mathrm{~h}$ prior to the experiment and maintained at ambient temperature, protected from light. The ABTS radical was diluted in ethanol PA until the absorbance reached $0.70 \pm 0.05$ at $734 \mathrm{~nm}$ and was incubated for $6 \mathrm{~min}$ with the extracts or controls at the concentrations used in the antioxidant assay. The volume of ABTS and extract used was $1980 \mu \mathrm{L}$ and $20 \mu \mathrm{L}$, respectively. The absorbance was read using a spectrophotometer (Quimis, Diadema, SP, Brazil) at $734 \mathrm{~nm}$. The results were expressed as $\%$ of free radical inhibition using 
formula (2). Three independent experiments were performed in triplicate.

Percent inibition of ABTS $(\%)=\frac{(\text { Abs control }- \text { Abs sample })}{\text { Abs controle }} \times 100$.

2.8.3. Hemolysis Oxidative Test Induced by 2,2'-Azobis(2amidinopropane) (AAPH). The protection effect of EEB and EEL against lipid peroxidation was evaluated by the method of oxidative hemolysis induced by $2,2^{\prime}$-azobis(2amidinopropane) dihydrochloride (AAPH, Sigma-Aldrich), described by Campos et al. [49]. After the approval of the Research Ethics Committee (REC) of the Federal University of Grande Dourados (UFGD) with the process number $5160,25 \mathrm{~mL}$ of blood was collected from a single, healthy, nonsmoking adult individual and stored in tubes containing the anticoagulant sodium citrate. From this sample, a $10 \%$ solution of red blood cells was prepared using $0.9 \% \mathrm{NaCl}$ solution.

The extracts (final concentrations of $10-125 \mu \mathrm{g} / \mathrm{mL}$ ) were preincubated with the erythrocyte solution at $37^{\circ} \mathrm{C}$ for $30 \mathrm{~min}$. After this period, $0.9 \% \mathrm{NaCl}$ solution or $50 \mathrm{mM}$ AAPH solution was added to investigate whether the extracts promote hemolysis in erythrocytes or inhibit oxidative hemolysis, respectively. The samples were incubated in a water bath at $37^{\circ} \mathrm{C}$ for $4 \mathrm{~h}$, and the mixture was homogenized steadily during this period. After 120, 180, and $240 \mathrm{~min}$, the samples were removed, centrifuged at $1500 \mathrm{rpm} / 10 \mathrm{~min}$, and then, the absorbance of the supernatant using a spectrophotometer (Quimis, Diadema, SP, Brazil) at $540 \mathrm{~nm}$ was read. The positive control ascorbic acid was maintained under the same conditions in assays. As a solvent control, the erythrocytes were incubated with ethanol at a final concentration of $0.4 \%$. Three independent experiments were performed in duplicates. The percent of hemolysis was determined using formula 3 , where the absorbance of total hemolysis represents erythrocytes incubated with distilled water.

$$
\text { Hemolysis }(\%)=\frac{\text { Abs sample }}{\text { Mean Abs total hemolysis }} \times 100 \text {. }
$$

2.8.4. Determination of Malondialdehyde (MDA). A byproduct of lipid peroxidation, MDA, was measured to assess the ability of extracts to protect erythrocytes against oxidative stress. For this, the ascorbic acid or extracts (final concentrations of $10-125 \mu \mathrm{g} / \mathrm{mL}$ ) were preincubated with erythrocyte suspension at $37^{\circ} \mathrm{C}$ for $30 \mathrm{~min}$. After this period, the oxidizing agent $\mathrm{AAPH}$, at $50 \mathrm{mM}$ concentration, was added and the mixture was incubated for $4 \mathrm{~h}$, under periodic agitation. After 120, 180, and $240 \mathrm{~min}$, the samples were centrifuged at $1500 \mathrm{rpm}$ for $10 \mathrm{~min}$ and $500 \mu \mathrm{L}$ of the remaining supernatant was added to $1 \mathrm{~mL}$ of $10 \mathrm{nM}$ thiobarbituric acid (TBA; Merck), solubilized in monosodium potassium phosphate buffer $(75 \mathrm{mM})$ at $\mathrm{pH} 2.5$. The control was prepared by the mixture of TBA and $20 \mathrm{mM}$ MDA solution. The samples were incubated in a water bath at $96^{\circ} \mathrm{C}$ for $45 \mathrm{~min}$.
TABle 1: Content of phenolic compounds, flavonoids, and condensed tannins in the EEB and EEL of $O$. minarum.

\begin{tabular}{lccc}
\hline Sample & $\begin{array}{c}\text { Phenolic compounds } \\
\text { (mg GAE/g) }\end{array}$ & $\begin{array}{c}\text { Flavonoids } \\
\text { (mg QE/g) }\end{array}$ & $\begin{array}{c}\text { Condensed tannins } \\
\text { (mg CAE/g) }\end{array}$ \\
\hline EEB & $156.4 \pm 3.1$ & $72.1 \pm 1.6$ & $16.1 \pm 0.2$ \\
EEL & $134.5 \pm 2.3$ & $78.5 \pm 1.4$ & $12.9 \pm 0.1$ \\
\hline
\end{tabular}

Subsequently, the reaction mixture was placed on an ice bath for $15 \mathrm{~min}$ to cease the reaction, and then, $4 \mathrm{~mL}$ of butanol was added to the mixture, with subsequent vortexing followed by centrifugation at $3000 \mathrm{rpm}$ for $5 \mathrm{~min}$, according to the method described by Campos et al. [50]. The absorbance of the supernatant was recorded using a spectrophotometer (Quimis, Diadema, SP, Brazil) at $532 \mathrm{~nm}$. The content of MDA is expressed as $\mathrm{nmol} / \mathrm{mL}$, obtained using

$$
\operatorname{MDA}(\mathrm{nmol} / \mathrm{mL})=\frac{\text { Abs sample }(20 \times 220.32)}{\text { Abs control }} .
$$

2.9. Statistical Analyses. The results are presented as the mean \pm standard error of the mean. The analysis of variance (ANOVA) followed by Dunnett's test was performed for the comparison between more than two experimental groups. The comparison between two experimental groups was performed by the Newman-Keuls test. The statistical analyses were performed using the statistical program GraphPad Prism 5 (GraphPad Software Inc., USA). The data were considered significant when the $P$ value was $<0.05$.

\section{Results}

3.1. Chemical Composition. The content of phenolic compounds and tannins in the EEB was higher than those in the EEL. The level of flavonoids in the EEL was higher than that in the EEB (Table 1).

The compounds were identified by HPLC and by the analysis of ultraviolet spectra of each peak. Caffeic acid $(15 \mathrm{~min})$ and rosmarinic acid $(53.7 \mathrm{~min})$ were identified in the EEB (Figures 1 and 2). In the EEL, caffeic acid (15.1 min), p-coumaric acid $(25.2 \mathrm{~min})$, rosmarinic acid (53.7 $\mathrm{min})$, quercetin $(59.1 \mathrm{~min})$, and luteolin $(59.7 \mathrm{~min}$ ) were identified (Figures 2 and 3).

3.2. Antimicrobial Activity. We evaluated the antimicrobial activity of different extracts against yeasts, gram-positive bacteria, and gram-negative bacteria (Tables 2 and 3). The HEEB was effective against all evaluated yeast strains, except against $R$. glutinis and $R$. mucilaginosa. The EEL, HYEL, and HEEB exhibited fungistatic and fungicidal action against C. krusei (Table 2).

The HYEB presented bacteriostatic and bactericidal action against the evaluated gram-positive bacteria. The EEL at a concentration of $1000 \mu \mathrm{g} / \mathrm{mL}$ showed antibacterial activity against all the evaluated gram-negative bacteria (Table 3). 


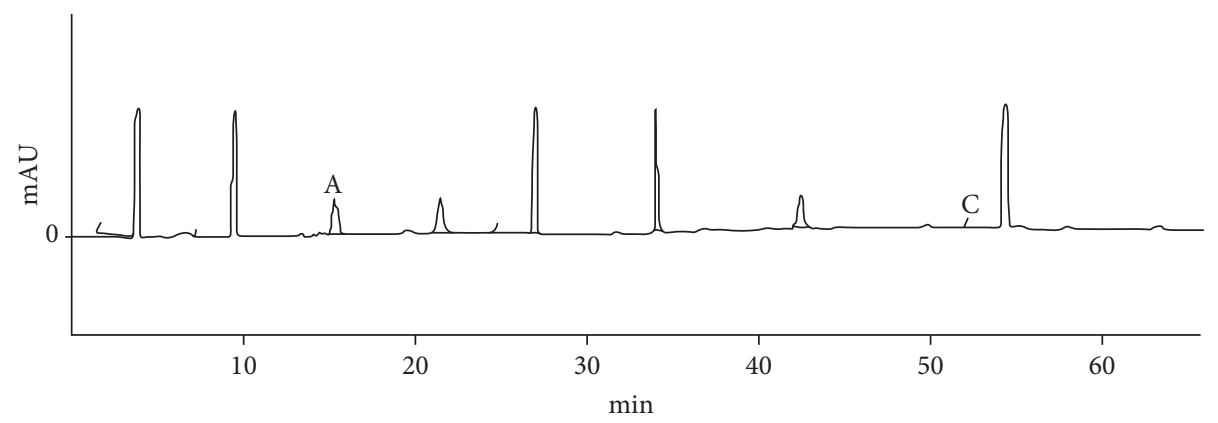

FIGURE 1: High-performance liquid chromatography of the EEB of Ocotea minarum. A caffeic acid (15 min). C rosmarinic acid (53.7 min).<smiles>O=C(O)CCc1ccc(O)c(O)c1</smiles>

Caffeic aicd<smiles>O=C(O)/C=C/c1ccc(O)c(O)c1</smiles>

(b)<smiles>[R20]C(Cl)(Cl)Cl</smiles>

(c)<smiles>O=c1c(O)c(-c2ccc(O)c(O)c2)oc2cc(O)cc(O)c12</smiles>

Quercetin

(d)<smiles>O=c1cc(-c2ccc(O)c(O)c2)oc2cc(O)cc(O)c12</smiles>

(e)

FIgURE 2: Compounds identified by high-performance liquid chromatography of the ethanolic extract from bark (EEB) and leaves (EEL) of Ocotea minarum.

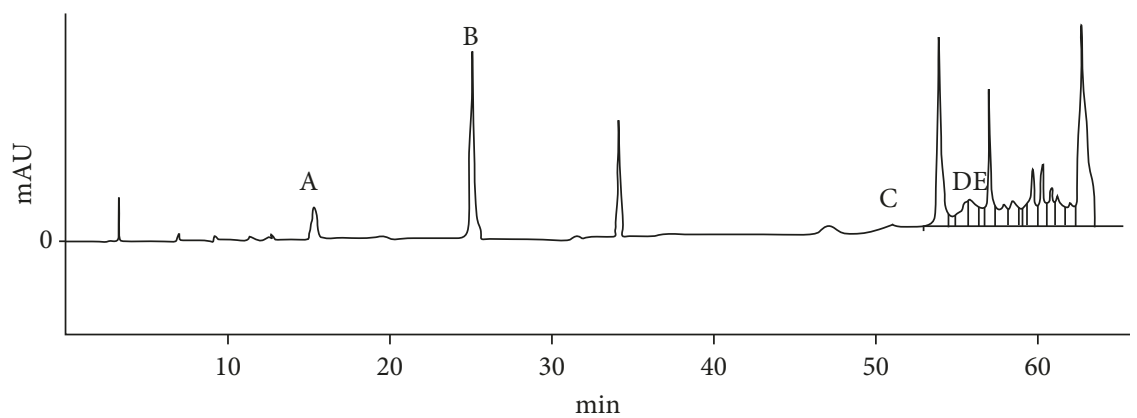

FIGURE 3: High-performance liquid chromatography of the EEL of Ocotea minarum. A caffeic acid (15.1 min). B p-coumaric acid (25.2 min). C rosmarinic acid (53.7 min). D quercetin (59.1 min). E luteolin (59.7 min).

\subsection{Antioxidant Activity}

3.3.1. Antioxidant Activity of Extracts by the DPPH and ABTS Assays. The results are expressed as the $\mathrm{IC}_{50}$ value and maximal activity of both the extracts (Table 4). The EEB had $\mathrm{IC}_{50}$ results similar to those of the antioxidant control, ascorbic acid, in both assays. Additionally, it presented superior results compared to the synthetic antioxidant $\mathrm{BHT}$, requiring concentrations 1.3 and 2.2 times smaller to inhibit $50 \%$ of DPPH and ABTS free radicals, respectively. The EEL had $\mathrm{IC}_{50}$ results similar to those of the BHT in both assays; however, it showed less activity than the standard antioxidant ascorbic acid.

3.3.2. Hemolytic Activity. After $4 \mathrm{~h}$ of incubation (Figure 4), ascorbic acid did not induce hemolysis at the evaluated 


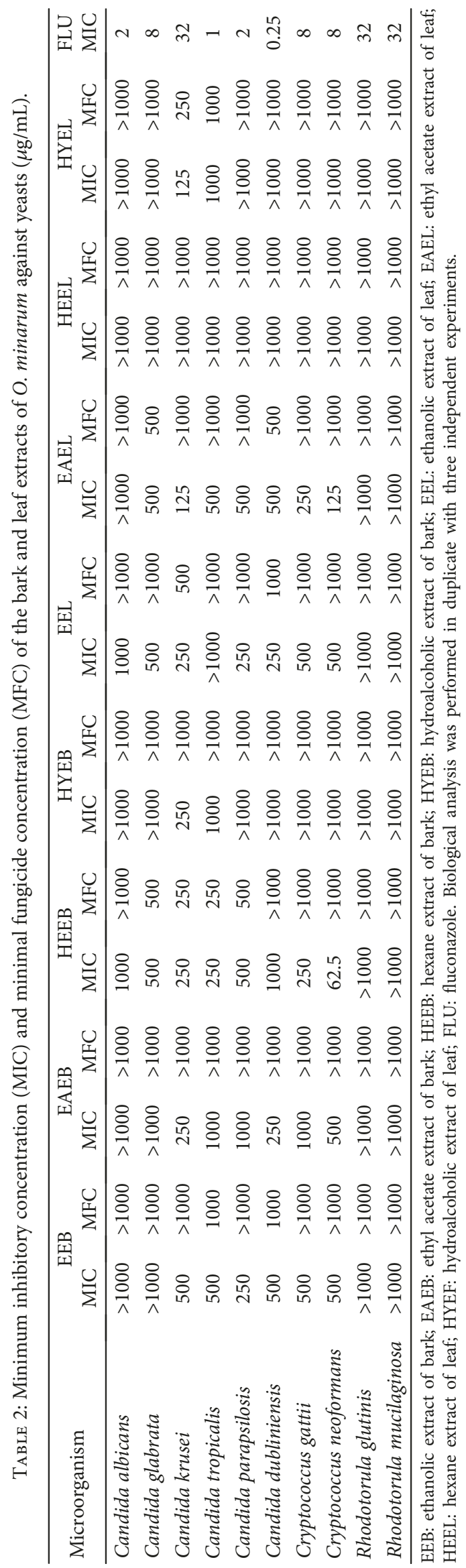




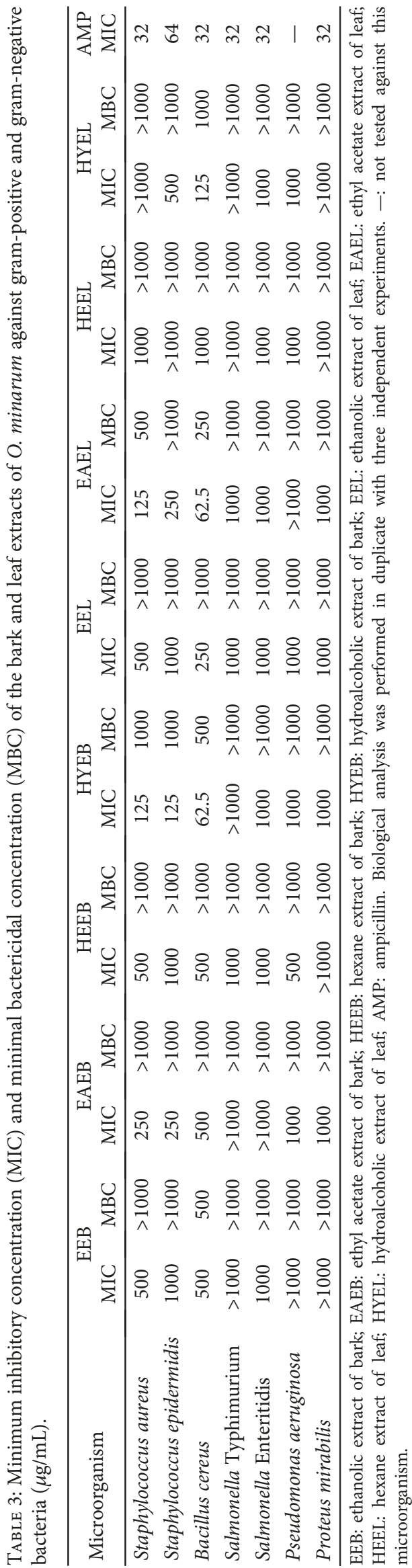


TABLE 4: Antioxidant activity of free radical capture DPPH and ABTS of extracts EEB and EEL of O. minarum and from the standard antioxidants: ascorbic acid (AA) and BHT.

\begin{tabular}{|c|c|c|c|c|c|c|}
\hline \multirow{3}{*}{ Samples } & \multicolumn{3}{|c|}{$\mathrm{DPPH}$} & \multicolumn{3}{|c|}{ ABTS } \\
\hline & \multirow{2}{*}{$\mathrm{IC}_{50}(\mu \mathrm{g} / \mathrm{mL})$} & \multicolumn{2}{|c|}{ Maximal activity } & \multirow{2}{*}{$\mathrm{IC}_{50}(\mu \mathrm{g} / \mathrm{mL})$} & \multicolumn{2}{|c|}{ Maximal activity } \\
\hline & & $\mu \mathrm{g} / \mathrm{mL}$ & $\%$ & & $\mu \mathrm{g} / \mathrm{mL}$ & $\%$ \\
\hline $\mathrm{AA}$ & $4.36 \pm 1.63$ & 10 & 95.58 & $1.16 \pm 0.14$ & 5 & 99.61 \\
\hline BHT & $6.07 \pm 0.79$ & 50 & 86.13 & $6.42 \pm 0.43$ & 50 & 97.88 \\
\hline EEB & $4.51 \pm 0.49$ & 10 & 83.93 & $2.87 \pm 0.42$ & 10 & 94.32 \\
\hline EEL & $8.19 \pm 1.25$ & 50 & 90.12 & $6.25 \pm 0.89$ & 50 & 95.59 \\
\hline
\end{tabular}

$\mathrm{IC}_{50}$, required concentration to capture $50 \%$ of the free radicals in the reaction. Values are the means \pm standard error of the mean (SEM).

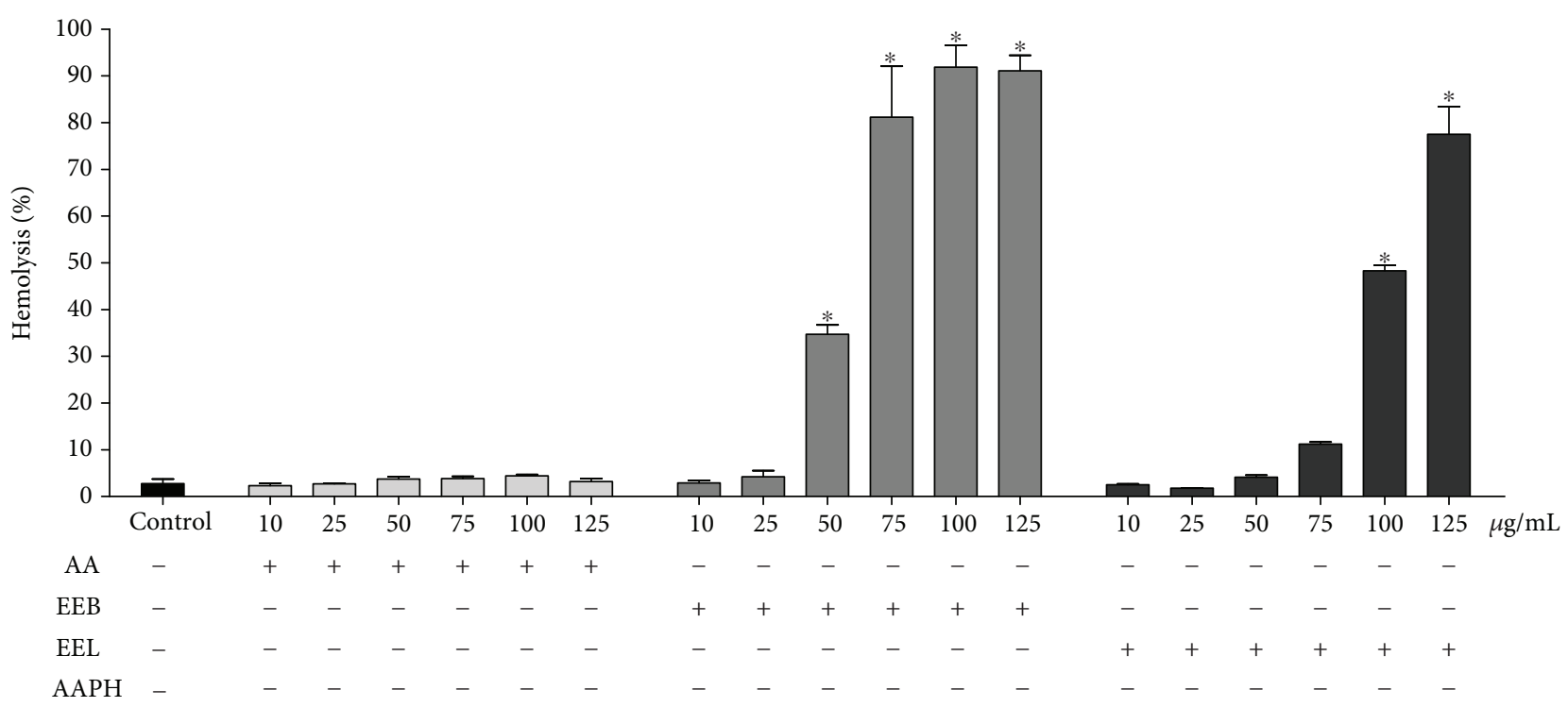

FIgURE 4: Hemolysis evaluation in human erythrocytes incubated for $4 \mathrm{~h}$ with the antioxidant standard ascorbic acid (AA) and ethanolic extract of bark (EEB) and leaves (EEL) of $O$. minarum at concentrations of $10-125 \mu \mathrm{g} / \mathrm{mL} .{ }^{*} P>0.05$ vs. control.

concentrations. The EEB and EEL showed a pattern similar to that of the control ascorbic acid, not inducing hemolysis at lower concentrations. However, they induced hemolysis at concentrations of $>25 \mu \mathrm{g} / \mathrm{mL}$ in $\mathrm{EEB}$ and $>100 \mu \mathrm{g} / \mathrm{mL}$ in EEL.

\subsubsection{Protection against Oxidative Hemolysis. After assessing} the hemolytic activity of extracts in human erythrocytes, the protective activity of EEB and EEL was observed in the erythrocytes subjected to oxidative hemolysis by AAPH (Figure 5). At 120 and $180 \mathrm{~min}$ (Figures 5(a) and 5(b)), the extracts exhibited protective action against oxidative hemolysis at the lowest concentrations of 10 to $100 \mu \mathrm{g} / \mathrm{mL}$. At $240 \mathrm{~min}$, only the EEB at a concentration of $25 \mu \mathrm{g} / \mathrm{mL}$ maintained this activity compared with that of the AAPH control (Figure 5(c)).

3.3.4. Generation of Malondialdehyde. The capacity of the extracts to protect erythrocytes incubated with the oxidizing agent AAPH against lipid peroxidation was assessed by the generation of MDA. At $120 \mathrm{~min}$, the erythrocytes incubated with $\mathrm{EEB}$ at concentrations of 10 and $25 \mu \mathrm{g} / \mathrm{mL}$ showed a reduction in the generation of MDA by approximately $83 \%$, when compared with that of the AAPH control group (Figure 6(a)). When incubated with the EEL at concentrations of 10 to $100 \mu \mathrm{g} / \mathrm{mL}$, there was a reduction in the formation of MDA by approximately $85 \%$.

In addition, at $180 \mathrm{~min}$ (Figure 6(b)), only the EEL reduced the formation of MDA by approximately $40 \%$ at concentrations of 10 to $100 \mu \mathrm{g} / \mathrm{mL}$ and, at $240 \mathrm{~min}$, reduced in $47 \%$ the formation of MDA, at a concentration of $100 \mu \mathrm{g} / \mathrm{mL}$, which was significantly different from that of the AAPH group (Figure 6(c)).

\section{Discussion}

Medicinal plants are sources of important biomolecules, including phenolic compounds, which are described as having various biological activities as antibacterial, antifungal, anti-inflammatory, antioxidant, and antitumor. The phenolic compounds caffeic acid and p-coumaric acid, identified by HPLC in the extracts of $O$. minarum, have already been related to antioxidant and antimicrobial activities in plants [51, 52]. 


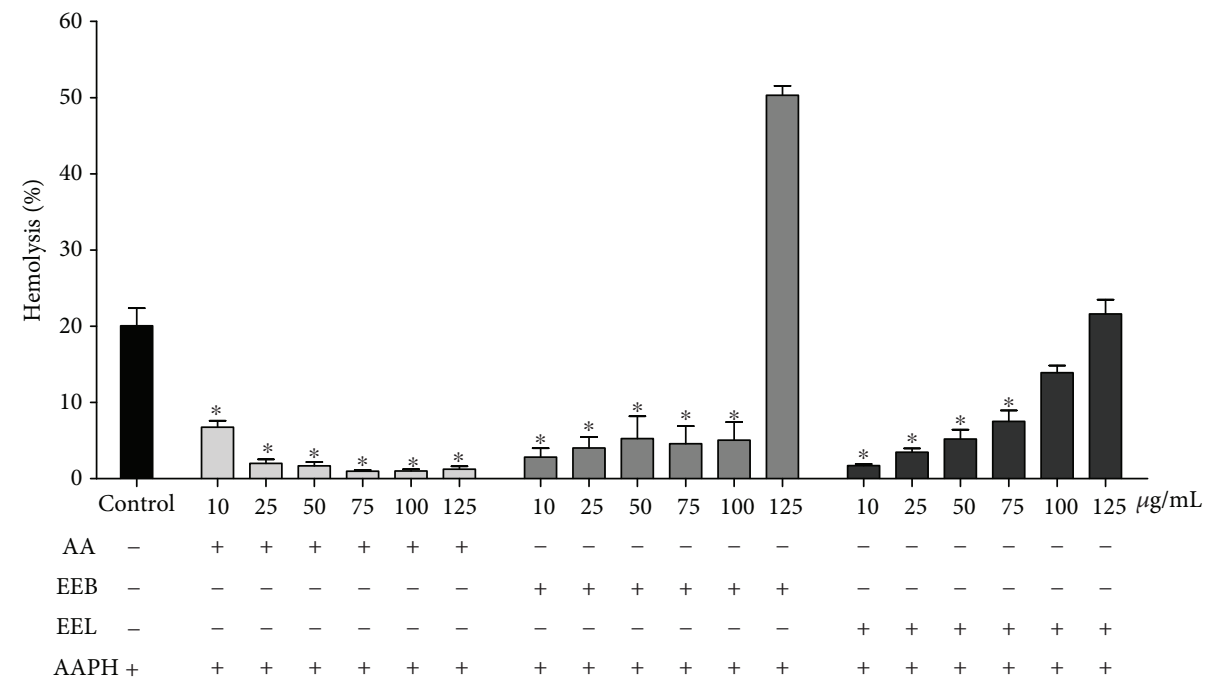

(a)

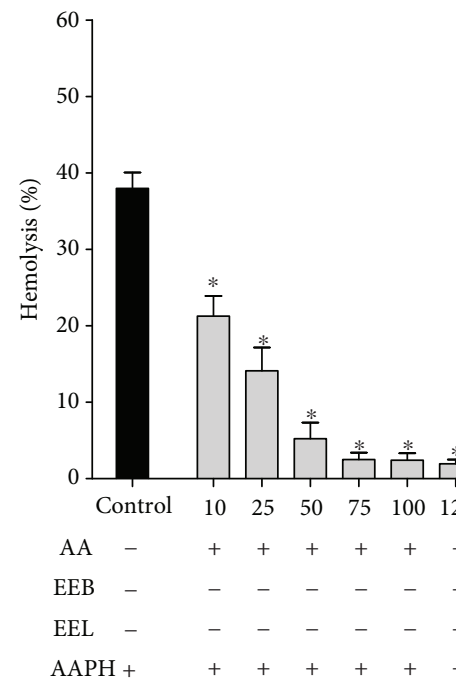

(b)

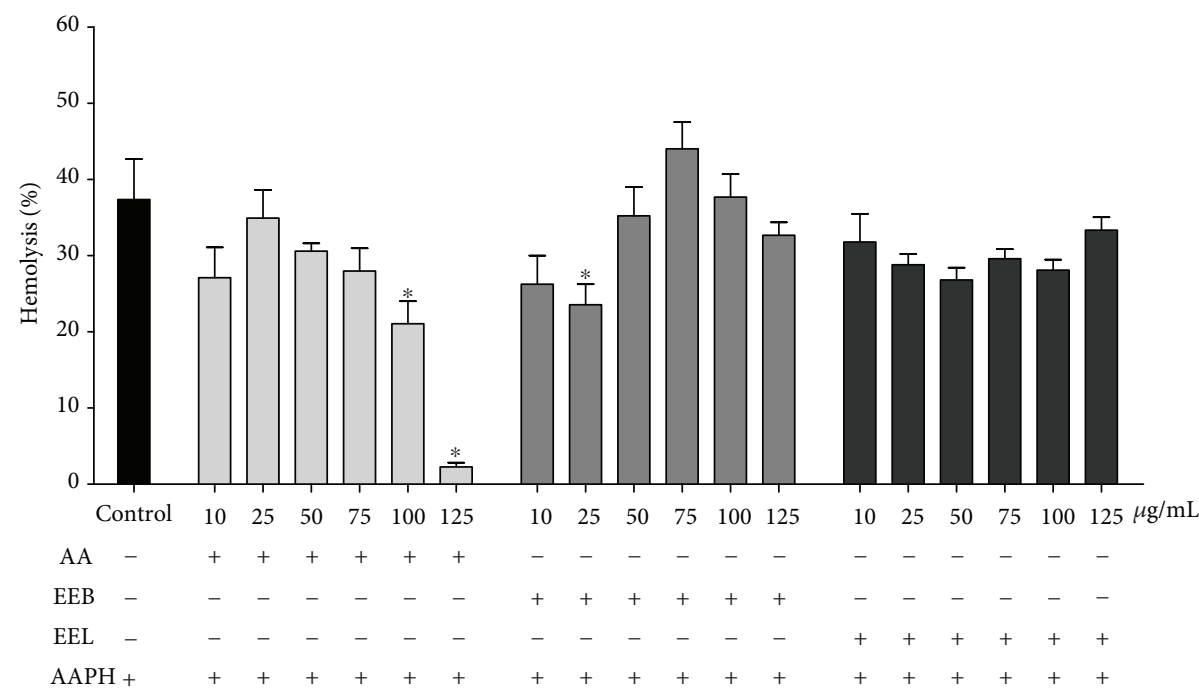

(c)

FIGURE 5: Assessment of hemolysis in human erythrocytes incubated for (a) 120, (b) 180, and (c) 240 min with the oxidizing agent AAPH with different concentrations of ascorbic acid, EEB, and EEL $(10-125 \mu \mathrm{g} / \mathrm{mL}) .{ }^{*} P>0.05$ vs. the AAPH control group. 


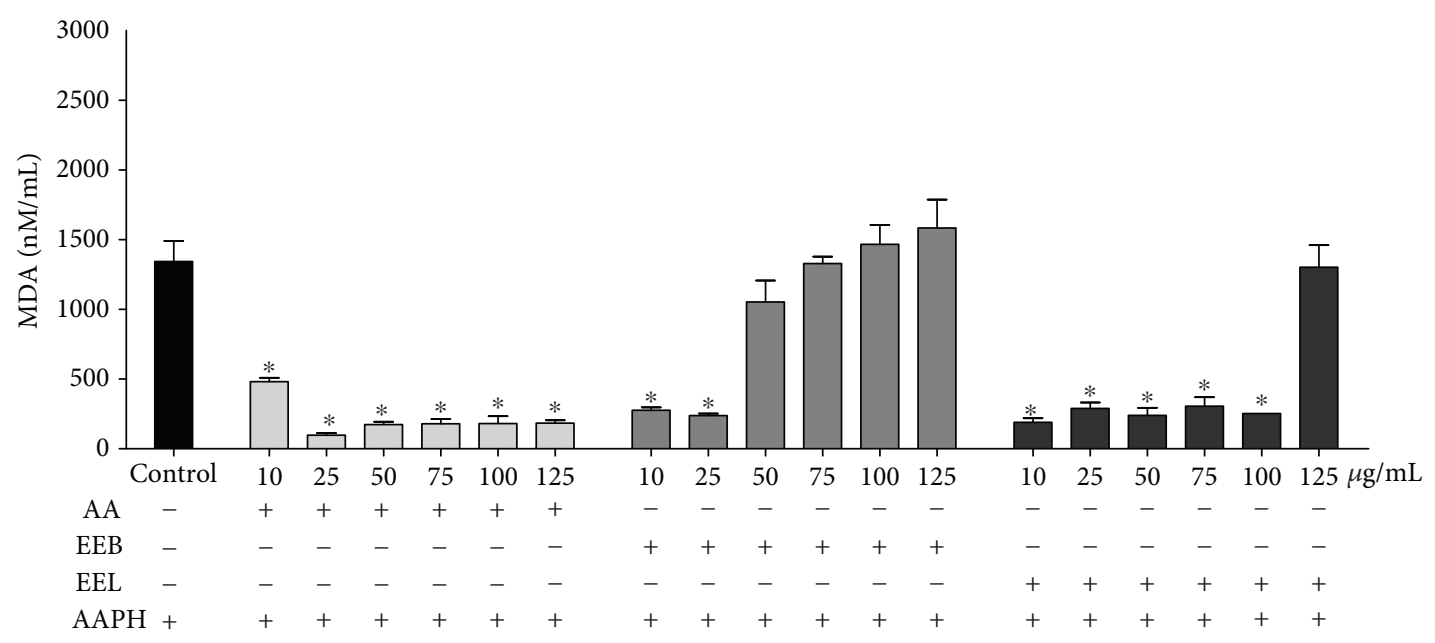

(a)

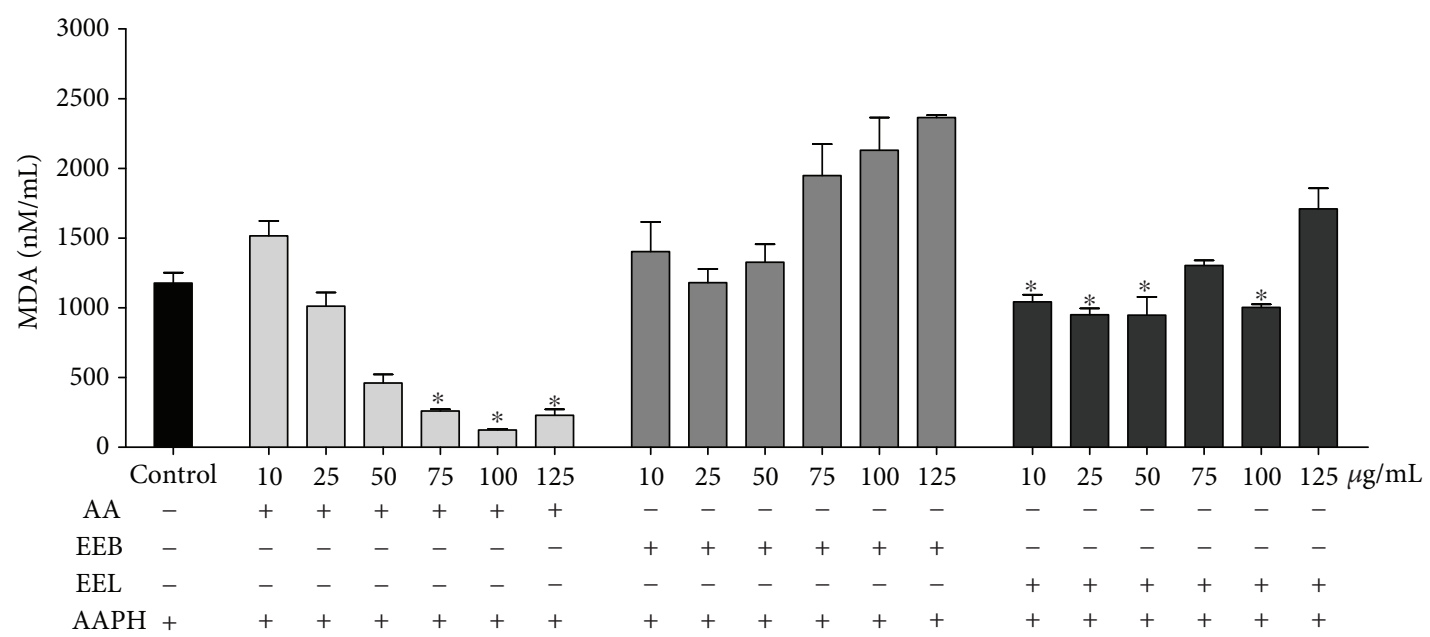

(b)

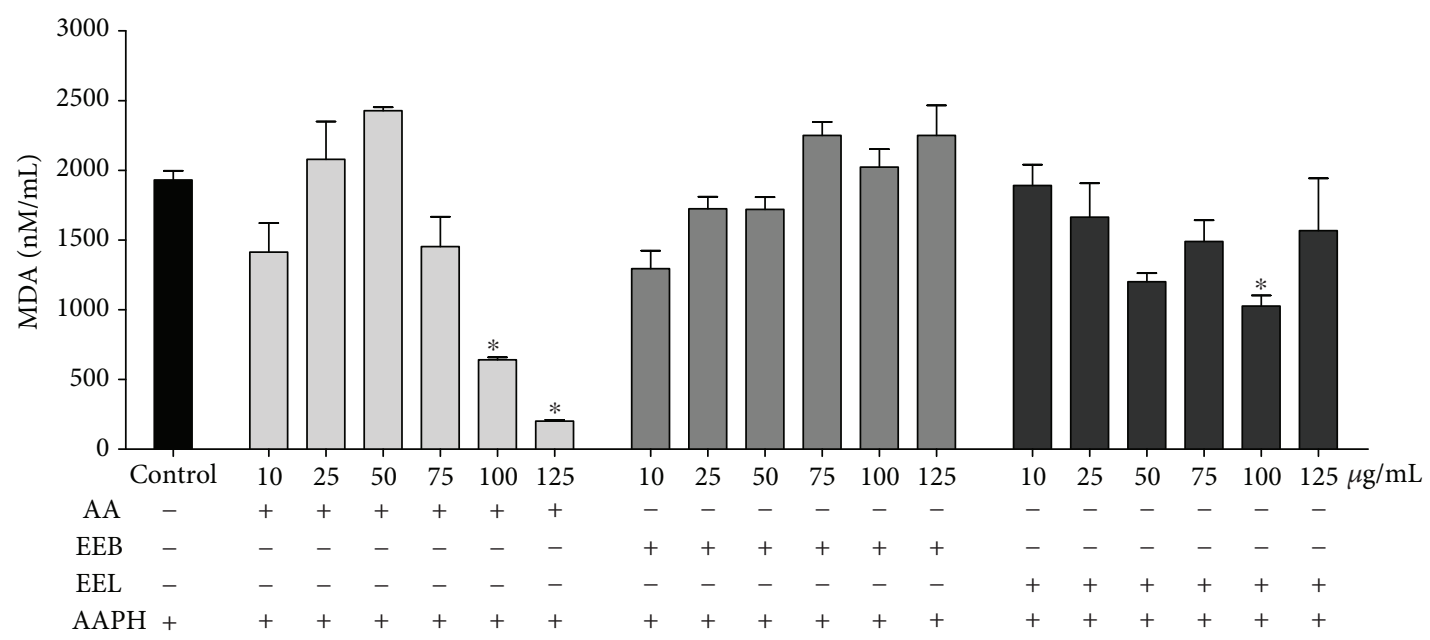

(c)

FIGURE 6: Concentration of malondialdehyde (MDA) in human erythrocytes incubated for (a) 120, (b) 180, and (c) 240 min with the oxidizing agent AAPH with different concentrations of ascorbic acid, EEB, and EEL $(10-125 \mu \mathrm{g} / \mathrm{mL}) .{ }^{*} P>0.05$ vs. the AAPH control group.

The extracts of $O$. minarum inhibited the growth of 15 out of seventeen microorganisms evaluated by the broth microdilution assay. Microorganisms have several defense mechanisms; gram-positive cells have only one lipopolysaccharide-phospholipid layer, thus conferring a higher penetration sensitivity of antibiotic substances, 
whereas gram-negative cells have a double layer of lipopolysaccharide-phospholipid, hindering the passage of molecules into the bacterial cell [53]. There are also mechanisms for the efflux of small molecules, inactivation of enzymes, and loss of porins in the plasma membrane $[54,55]$. Furthermore, some yeasts, such as Cryptococcus sp. and Rhodotorula sp., are encapsulated, which confer them greater protection [56].

According to Morales et al. [57] different parameters of antimicrobial activity were considered: $\mathrm{MIC}<100 \mu \mathrm{g} /$ $\mathrm{mL}$, active; MIC $100-500 \mu \mathrm{g} / \mathrm{mL}$, moderate; MIC $500-$ $1000 \mu \mathrm{g} / \mathrm{mL}$, weak antimicrobial activity; and MIC $>1000$ $\mu \mathrm{g} / \mathrm{mL}$, inactive. Based on the adopted criteria, the EHEB showed good antifungal activity against $C$. neoformans and moderate activity against C. tropicalis, C. gattii, and C. krusei. Cryptococcus neoformans might have gained resistance to fluconazole, and C. krusei is intrinsically resistant to the same antifungal agent and is often isolated from opportunistic and invasive infections caused by Candida species [58]. Therefore, a search for new techniques for the development of new antimicrobials is important to improve the treatment of infections. With respect to gram-positive bacteria, in the present study, the EAEL and HYEB showed good antibacterial activity against Bacillus cereus and moderate activity against $S$. aureus and $S$. epidermidis.

Bruni et al. [29] showed the antibacterial activity of the essential oil of Ocotea quixos flowers against $S$. aureus and E. faecalis. Gil et al. [27] demonstrated that the essential oil of Ocotea caudata leaves has antibacterial action against $B$. subtilis and $S$. aureus. In the present study, the EEB and EEL of O. minarum did not present active antibacterial action against gram-negative bacteria. This suggests that the extracts probably act on the cell wall and peptidoglycan bonds of gram-positive bacteria and do not have good activity against the gram-negative bacteria due to the presence of a double layer of lipopolysaccharide-phospholipid, conferring less sensitivity.

The antimicrobial activity exhibited by the EEB and EEL of $O$. minarum is probably due to the presence of sesquiterpenes: lanceolic acid, curcumen-12-oic acid, (+)-Eexo-abergamoten-12-oico acid, loliolide terpene lactone, and nor-sesquiterpene [37]. The flavonoids quercetin and luteolin, present in EEB and EEL, have been associated with antimicrobial activity, as they can penetrate cellular phospholipid membranes due to their hydrophobicity $[59,60]$. To the best of our knowledge, the present study is the first to report the antibacterial activity of $O$. minarum.

Further, the phenolic acids caffeic acid and p-coumaric acid and the flavonoid quercetin identified are also associated with antioxidant activity, due to their direct action in the capture of free radicals [61-63]. The EEB and EEL exhibited promising antioxidant activity in the DPPH and ABTS assay, when compared with that of ascorbic and BHT, reference antioxidants. In particular, EEB presented a higher antioxidant potential than EEL in both the tests.

Other authors describe the antioxidant activity of species of the genus Ocotea $[25,29]$. Comparatively, in the present study, the EEB and EEL of O. minarum showed a better antioxidant potential than other species of the same genus.
The redox balance of the body is regulated by endogenous and exogenous mechanisms, in which the excess of free radicals is a fundamental factor causing numerous diseases, such as diabetes, atherosclerosis, cardiovascular diseases, cancer, and premature aging, among others [11]. Therefore, the search for natural antioxidants has increased in order to replace the synthetic compounds that might pose harmful effects on human health [64].

When evaluating the antioxidant properties of extracts in human erythrocytes, although the EEB and EEL at the highest concentrations induced high hemolysis rates, both promoted the reduction of AAPH-induced lipid peroxidation at lower doses and during the early evaluation times, protecting the erythrocytes from cell lysis. The peroxidation of the phospholipid membrane is induced by reactive species, especially oxygen and nitrogen species, causing cell lysis and death. Furthermore, a byproduct of this reaction is malondialdehyde $[65,66]$, which is a toxic product leading to the release of unsaturated fatty acids and the fragmentation of phospholipids, causing mutations and cellular rupture [19]. The EEB and EEL reduced the generation of malondialdehyde during the early evaluation times, contributing to the maintenance of a cellular structure, at low concentrations. Thus, protection against this type of cellular damage is considered a positive effect [11], as it is associated with the reduction of damage caused by oxidative stress and its complications.

Luteolin, a flavonoid present in the extract of the leaves of $O$. minarum, has been described by modulating the expression of antioxidant enzymes superoxide dismutase and catalase, besides reducing the levels of malondialdehyde generated in an oxidative stress model in vivo [67]. The flavonoid quercetin and the polyphenol rosmarinic acid, also identified in extracts of the O. minarum, have already been described by activation of the transcriptional factor Nrf-2 (nuclear factor erythroid 2), an important cell antioxidant mechanism [68, 69].

In conclusion, the data indicate that the $O$. minarum extracts can be evaluated as bioactive supplies for the development of new drugs for the prevention and treatment of diseases related to microbial infections and oxidative stress.

\section{Data Availability}

The chemical composition, antimicrobial, and antioxidant data used to support the findings of this study are included within the article.

\section{Conflicts of Interest}

The authors declare that there is no conflict of interest regarding the publication of this paper.

\section{Acknowledgments}

The authors thank the Fundação de Apoio ao Desenvolvimento do Ensino, Ciência e Tecnologia do Estado de Mato Grosso do Sul, (grant number 23/200.549/2013) and the Universidade Federal da Grande Dourados for the financial support. 


\section{References}

[1] J. J. Sajkowska-Kozielewicz, P. Kozielewicz, N. M. Barnes, I. Wawer, and K. Paradowska, "Antioxidant, cytotoxic, and antiproliferative activities and total polyphenol contents of the extracts of Geissospermum reticulatum bark," Oxidative Medicine and Cellular Longevity, vol. 2016, Article ID 2573580, 8 pages, 2016.

[2] K. Zurowska, Ziołolecznictwo Amazonskie i Andyjskie, Tower Press, Gdansk, Poland, 2001.

[3] K. Chhouk, Wahyudiono, H. Kanda, and M. Goto, "Efficacy of supercritical carbon dioxide integrated hydrothermal extraction of Khmer medicinal plants with potential pharmaceutical activity," Journal of Environmental Chemical Engineering, vol. 6, no. 2, pp. 2944-2956, 2018.

[4] O. Abioye, D. Akinpelu, and A. Okoh, "Synergistic effects of $n$ hexane fraction of Parkia biglobosa (Jacq.) bark extract and selected antibiotics on bacterial isolates," Sustainability, vol. 9, no. 2, p. 228, 2017.

[5] L. Catteau, F. van Bambeke, and J. Quetin-Leclercq, "Preliminary evidences of the direct and indirect antimicrobial activity of 12 plants used in traditional medicine in Africa," Phytochemistry Reviews, vol. 14, no. 6, pp. 975-991, 2015.

[6] N. Kacem, V. Roumy, N. Duhal et al., "Chemical composition of the essential oil from Algerian Genista quadriflora Munby and determination of its antibacterial and antifungal activities," Industrial Crops and Products, vol. 90, pp. 87-93, 2016.

[7] P. W. Su, C. H. Yang, J. F. Yang, P. Y. Su, and L. Y. Chuang, "Antibacterial activities and antibacterial mechanism of Polygonum cuspidatum extracts against nosocomial drug-resistant pathogens," Molecules, vol. 20, no. 6, pp. 11119-11130, 2015.

[8] H. Grundmann, M. de Kraker, and P. Davey, "Clinical impact of antimicrobial resistance: design matters," Lancet Infectious Diseases, vol. 11, no. 5, pp. 344-345, 2011.

[9] S. N. Bakal, S. Bereswill, and M. M. Heimesaat, "Finding novel antibiotic substances from medicinal plants - antimicrobial properties of Nigella sativa directed against multidrug resistant bacteria," European Journal of Microbiology and Immunology, vol. 7, no. 1, pp. 92-98, 2017.

[10] Z. Bey-Ould Si Said, H. Haddadi-Guemghar, L. BoulekbacheMakhlouf et al., "Essential oils composition, antibacterial and antioxidant activities of hydrodistillated extract of Eucalyptus globulus fruits," Industrial Crops and Products, vol. 89, pp. 167-175, 2016.

[11] P. P. d. T. Espindola, P. d. S. d. Rocha, C. A. Carollo et al., "Antioxidant and antihyperlipidemic effects of Campomanesia adamantium O. Berg root," Oxidative Medicine and Cellular Longevity, vol. 2016, Article ID 7910340, 8 pages, 2016.

[12] M. T. Elnakish, H. H. Hassanain, P. M. Janssen, M. G. Angelos, and M. Khan, "Emerging role of oxidative stress in metabolic syndrome and cardiovascular diseases: important role of Rac/NADPH oxidase," Journal of Pathology, vol. 231, no. 3, pp. 290-300, 2013.

[13] A. A. Mohamed, S. I. Ali, F. K. el-Baz, A. K. Hegazy, and M. A. Kord, "Chemical composition of essential oil and in vitro antioxidant and antimicrobial activities of crude extracts of Commiphora myrrha resin," Industrial Crops and Products, vol. 57, pp. 10-16, 2014.

[14] E. M. Silva, J. N. S. Souza, H. Rogez, J. F. Rees, and Y. Larondelle, "Antioxidant activities and polyphenolic contents of fifteen selected plant species from the Amazonian region," Food Chemistry, vol. 101, no. 3, pp. 1012-1018, 2007.
[15] J. Coccimiglio, M. Alipour, Z. H. Jiang, C. Gottardo, and Z. Suntres, "Antioxidant, antibacterial, and cytotoxic activities of the ethanolic Origanum vulgare extract and its major constituents," Oxidative Medicine and Cellular Longevity, vol. 2016, Article ID 1404505, 8 pages, 2016.

[16] K. Jomova and M. Valko, "Advances in metal-induced oxidative stress and human disease," Toxicology, vol. 283, no. 2-3, pp. 65-87, 2011.

[17] O. Politeo, M. Jukic, and M. Milos, "Chemical composition and antioxidant capacity of free volatile aglycones from basil (Ocimum basilicum L.) compared with its essential oil," Food Chemistry, vol. 101, no. 1, pp. 379-385, 2007.

[18] C. Lu, C. Li, B. Chen, and Y. Shen, "Composition and antioxidant, antibacterial, and anti-HepG2 cell activities of polyphenols from seed coat of Amygdalus pedunculata Pall," Food Chemistry, vol. 265, pp. 111-119, 2018.

[19] Y. Wang, O. Chun, and W. Song, "Plasma and dietary antioxidant status as cardiovascular disease risk factors: a review of human studies," Nutrients, vol. 5, no. 8, pp. 2969-3004, 2013.

[20] A. A. Mohamed, S. I. Ali, and F. K. El-Baz, "Antioxidant and antibacterial activities of crude extracts and essential oils of Syzygium cumini leaves," PLoS One, vol. 8, no. 4, article e60269, 2013.

[21] A. N. d. L. Batista, J. M. Batista Junior, S. N. López et al., "Aromatic compounds from three Brazilian Lauraceae species," Quimica Nova, vol. 33, no. 2, pp. 321-323, 2010.

[22] H. Van der Werff, "A synopsis of Ocotea (Lauraceae) in Central America and Southern Mexico," Annals of the Missouri Botanical Garden, vol. 89, no. 3, pp. 429-451, 2002.

[23] J. B. Baitello, "New species of Lauraceae for Brazilian flora," Acta Botanica Brasilica, vol. 15, no. 3, pp. 445-450, 2010.

[24] A. Quinet, J. B. Baitello, P. L. R. Moraes, L. de Assi, and F. M. Alves, Lauraceae in Lista de Espécies da Flora do Brasil, Jardim Botânico do Rio de Janeiro, 2015, http://floradobrasil.jbrj.gov .br/jabot/floradobrasil/FB8471.

[25] D. T. da Silva, R. Herrera, B. F. Batista, B. M. Heinzmann, and J. Labidi, "Physicochemical characterization of leaf extracts from Ocotea lancifolia and its effect against wood-rot fungi," International Biodeterioration and Biodegradation, vol. 117, pp. 158-170, 2017.

[26] A. Rigobert, R. Rahanira, A. Onja, R. Delphin, R. Laurence, and R. Rado, "Chemical composition, antioxidant and antibacterial properties of essential oil from Ocotea Auriculiformis Kost. (Lauraceae) leaves, endemic of Madagascar," European Scientific Journal, vol. 13, no. 33, pp. 364-377, 2017.

[27] E. Gil, L. E. Cuca, and W. A. Delgado, "Chemical composition and antimicrobial activity of the essential oil of the leaves of Ocotea caudata (Nees) Mez (Lauraceae) from Colombia," Boletín Latinoamericano y del Caribe de Plantas Medicinales y Aromáticas, vol. 15, no. 4, pp. 258-263, 2016.

[28] R. D. Castro and E. O. Lima, "Antifungal activity of Brazilian sassafras (Ocotea odorifera Vell.) and rosemary (Rosmarinus officinalis L.) essential oils against the genus Candida," Revista Brasileira de Plantas Medicinais, vol. 13, no. 2, pp. 203-208, 2011.

[29] R. Bruni, A. Medici, E. Andreotti et al., "Chemical composition and biological activities of Ishpingo essential oil, a traditional Ecuadorian spice from Ocotea quixos (Lam.) Kosterm. (Lauraceae) flower calices," Food Chemistry, vol. 85, no. 3, pp. 415-421, 2004. 
[30] A. L. Ogundajo, L. A. Adeniran, and A. O. Ashafa, "Medicinal properties of Ocotea bullata stem bark extracts: phytochemical constituents, antioxidant and anti-inflammatory activity, cytotoxicity and inhibition of carbohydrate-metabolizing enzymes," Journal of Integrative Medicine, vol. 16, no. 2, pp. 132-140, 2018.

[31] K. K. d. L. Yamaguchi, J. M. Alcântara, and V. F. d. Veiga Junior, "Antioxidant and anticholinesterasic effects of 20 species of the family Lauraceae," Acta Amazonica, vol. 42, no. 4, pp. 541-546, 2012.

[32] A. Guerrini, G. Sacchetti, M. Muzzoli et al., "Composition of the volatile fraction of Ocotea bofo Kunth (Lauraceae) calyces by GC-MS and NMR fingerprinting and its antimicrobial and antioxidant activity," Journal of Agricultural and Food Chemistry, vol. 54, no. 20, pp. 7778-7788, 2006.

[33] R. A. Destryana, D. Gary Young, C. L. Woolley, T. C. Huang, H. Y. Wu, and W. L. Shih, "Antioxidant and antiinflammation activities of Ocotea, copaiba and blue cypress essential oils in vitro and in vivo," Journal of the American Oil Chemists' Society, vol. 91, no. 9, pp. 1531-1542, 2014.

[34] A. Fournet, M. E. Ferreira, A. Rojas de Arias, I. Guy, H. Guinaudeau, and H. Heinzen, "Phytochemical and antiprotozoal activity of Ocotea lancifolia," Fitoterapia, vol. 78, no. 5, pp. 382-384, 2007.

[35] P. L. R. de Moraes, "Synopsis of Lauraceas in the states of Goias and Tocantins, Brazil," Biota Neotrópica, vol. 5, no. 2, pp. 1-18, 2005.

[36] V. Vecchietti, C. Casagrande, G. Ferrari, and G. Severini Ricca, "New aporphine alkaloids of Ocotea minarum," Il Farmaco; Edizione Scientifica, vol. 34, no. 10, pp. 829-840, 1979.

[37] W. S. Garcez, F. R. Garcez, L. M. G. E. d. Silva, and A. A. Shimabukuro, "Indole alkaloid and other constituents from Ocotea minarum," Journal of the Brazilian Chemical Society, vol. 16, no. 6b, pp. 1382-1386, 2005.

[38] F. J. A. Matos, Introduction to Experimental Phytochemistry,, Issues UFC, Fortaleza, Brazil, 3rd edition, 2009.

[39] A. Djeridane, M. Yousfi, B. Nadjemi, D. Boutassouna, P. Stocker, and N. Vidal, "Antioxidant activity of some Algerian medicinal plants extracts containing phenolic compounds," Food Chemistry, vol. 97, no. 4, pp. 654-660, 2006.

[40] J. Y. Lin and C. Y. Tang, "Determination of total phenolic and flavonoid contents in selected fruits and vegetables, as well as their stimulatory effects on mouse splenocyte proliferation," Food Chemistry, vol. 101, no. 1, pp. 140-147, 2007.

[41] R. B. Broadhurst and W. T. Jones, "Analysis of condensed tannins using acidified vanillin," Journal of the Science of Food and Agriculture, vol. 29, no. 9, pp. 788-794, 1978.

[42] T. S. Agostini-Costa, D. S. Garriti, L. Lima, S. Freire, F. A. P. Abreu, and T. Feitosa, "Avaliação de metodologias para determinação de taninos no suco de caju," Boletim CEPPA, vol. 17, no. 2, pp. 167-176, 1999.

[43] A. Kumaran and R. Joel karunakaran, "Antioxidant and free radical scavenging activity of an aqueous extract of Coleus aromaticus," Food Chemistry, vol. 97, no. 1, pp. 109-114, 2006.

[44] CLSI, Reference Method for Broth Dilution Antifungal Susceptibility Testing of Yeasts. Approved Standard. CLSI document M27-A3, Clinical and Laboratory Standards Institute, Wayne, PA, USA, 3rd edition edition, 2008.

[45] CLSI, Methods for Dilution Antimicrobial Susceptibility Tests $f$ or Bacteria That Grow Aerobically. Approved Standard. CLSI document M07-A9, Clinical and Laboratory Standards Institute, Wayne, PA, USA, 9th edition edition, 2012.

[46] R. V. Bagiu, B. Vlaicu, and M. Butnariu, "Chemical composition and in vitro antifungal activity screening of the Allium ursinum L. (Liliaceae)," International Journal of Molecular Sciences, vol. 13, no. 2, pp. 1426-1436, 2012.

[47] P. Sharma, A. B. Jha, R. S. Dubey, and M. Pessarakli, "Reactive oxygen species, oxidative damage, and antioxidative defense mechanism in plants under stressful conditions," Journal of Botany, vol. 2012, Article ID 217037, 26 pages, 2012.

[48] R. Re, N. Pellegrini, A. Proteggente, A. Pannala, M. Yang, and C. Rice-Evans, "Antioxidant activity applying an improved ABTS radical cation decolorization assay," Free Radical Biology and Medicine, vol. 26, no. 9-10, pp. 1231-1237, 1999.

[49] J. F. Campos, U. P. d. Santos, P. d. S. d. Rocha et al., "Antimicrobial, antioxidant, anti-inflammatory, and cytotoxic activities of propolis from the stingless bee Tetragonisca fiebrigi (Jataí)," Evidence-Based Complementary and Alternative Medicine, vol. 2015, Article ID 296186, 11 pages, 2015.

[50] J. F. Campos, U. P. dos Santos, L. F. B. Macorini et al., “Antimicrobial, antioxidant and cytotoxic activities of propolis from Melipona orbignyi (Hymenoptera, Apidae)," Food and Chemical Toxicology, vol. 65, pp. 374-380, 2014.

[51] P. R. B. Broinizi, E. R. S. Andrade-Wartha, A. M. Oliveira e Silva et al., "Evaluation of the antioxidant activity of phenolic compounds naturally contained in by-products of the cashew apple (Anacardium occidentale L.)," Ciência e Tecnologia de Alimentos, vol. 27, no. 4, pp. 902-908, 2007.

[52] V. C. Ramalho and N. Jorge, "Antioxidants used in oils, fats and fatty foods," Química Nova, vol. 29, no. 4, pp. 755-760, 2006.

[53] K. Caumo, M. Duarte, S. T. Cargnin, V. B. Ribeiro, T. Tasca, and A. J. Macedo, "Bacterial resistance to the environment and implications in the hospital clinic," Revista Liberato, vol. 11, no. 16, pp. 89-188, 2010.

[54] C. Walsh, "Molecular mechanisms that confer antibacterial drug resistance," Nature, vol. 406, no. 6797, pp. 775-781, 2000.

[55] J. F. Fisher, S. O. Meroueh, and S. Mobashery, "Bacterial resistance to $\beta$-lactam antibiotics: compelling opportunism, compelling opportunity," Chemical Reviews, vol. 105, no. 2, pp. 395-424, 2005.

[56] I. D. Dos Santos JR., I. A. M. Souza, R. G. Borges, L. B. S. De Souza, W. J. De Santana, and H. D. M. Coutinho, "General traits of action, treatment and fungal resistance to fluconazole," Scientia Medica, vol. 15, no. 3, pp. 189-197, 2005.

[57] G. Morales, A. Paredes, P. Sierra, and L. Loyola, "Antimicrobial activity of three baccharis species used in the traditional medicine of Northern Chile," Molecules, vol. 13, no. 4, pp. 790-794, 2008.

[58] A. L. Colombo, D. da Matta, L. P. de Almeida, and R. Rosas, "Fluconazole susceptibility of Brazilian Candida isolates assessed by a disk diffusion method," Brazilian Journal of Infectious Diseases, vol. 6, no. 3, pp. 118-123, 2002.

[59] M. Daglia, "Polyphenols as antimicrobial agents," Current Opinion in Biotechnology, vol. 23, no. 2, pp. 174-181, 2012.

[60] J. Alvesalo, H. Vuorela, P. Tammela, M. Leinonen, P. Saikku, and P. Vuorela, "Inhibitory effect of dietary phenolic compounds on chlamydia pneumoniae in cell cultures," Biochemical Pharmacology, vol. 71, no. 6, pp. 735-741, 2006.

[61] E. B. Behling, M. C. Sendão, H. D. Francescato, L. M. Antunes, and M. L. Bianchi, "Flavonoid quercetin: general aspects and 
biological actions," Alimentos e Nutrição Araraquara, vol. 15, no. 3, pp. 285-292, 2004.

[62] Y. Sorata, U. Takahama, and M. Kimura, "Protective effect of quercetin and rutin on photosensitized lysis of human erythrocytes in the presence of hematoporphyrin," Biochimica et Biophysica Acta (BBA) - General Subjects, vol. 799, no. 3, pp. 313-317, 1984.

[63] P. P. Singh and S. M. S. Chauhan, "Activity-guided isolation of antioxidants from the leaves of Terminalia arjuna," Natural Product Research, vol. 28, no. 10, pp. 760-763, 2013.

[64] J. J. B. Jandú, L. C. N. da Silva, A. P. C. Pereira et al., "Myracrodruon urundeuva bark: an antimicrobial, antioxidant and noncytotoxic agent," Journal of Medicinal Plants Research, vol. 7, no. 8, pp. 413-418, 2013.

[65] I. Kuliaviene, A. Gulbinas, J. Cremers et al., "Fatty acids of erythrocyte membrane in acute pancreatitis patients," World Journal of Gastroenterology, vol. 19, no. 34, pp. 5678-5684, 2013.

[66] R. C. Chisté, M. Freitas, A. Z. Mercadante, and E. Fernandes, "Carotenoids inhibit lipid peroxidation and hemoglobin oxidation, but not the depletion of glutathione induced by ROS in human erythrocytes," Life Sciences, vol. 99, no. 1-2, pp. 52-60, 2014.

[67] H. Qiao, L. Dong, X. Zhang et al., "Protective effect of luteolin in experimental ischemic stroke: upregulated SOD1, CAT, Bcl-2 and claudin-5, down-regulated MDA and Bax expression," Neurochemical Research, vol. 37, no. 9, pp. 2014-2024, 2012.

[68] J. Govindaraj and S. Sorimuthu Pillai, "Rosmarinic acid modulates the antioxidant status and protects pancreatic tissues from glucolipotoxicity mediated oxidative stress in high-fat diet: streptozotocin-induced diabetic rats," Molecular and Cellular Biochemistry, vol. 404, no. 1-2, pp. 143-159, 2015.

[69] S. Ozgen, O. K. Kilinc, and Z. Selamoglu, “Antioxidant activity of quercetin: a mechanistic review," Turkish Journal of Agriculture - Food Science and Technology, vol. 4, no. 12, p. 1134, 2016. 


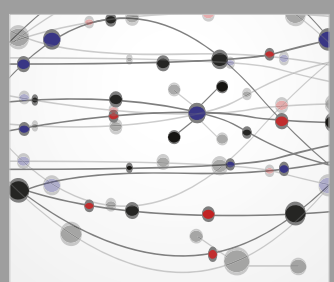

The Scientific World Journal
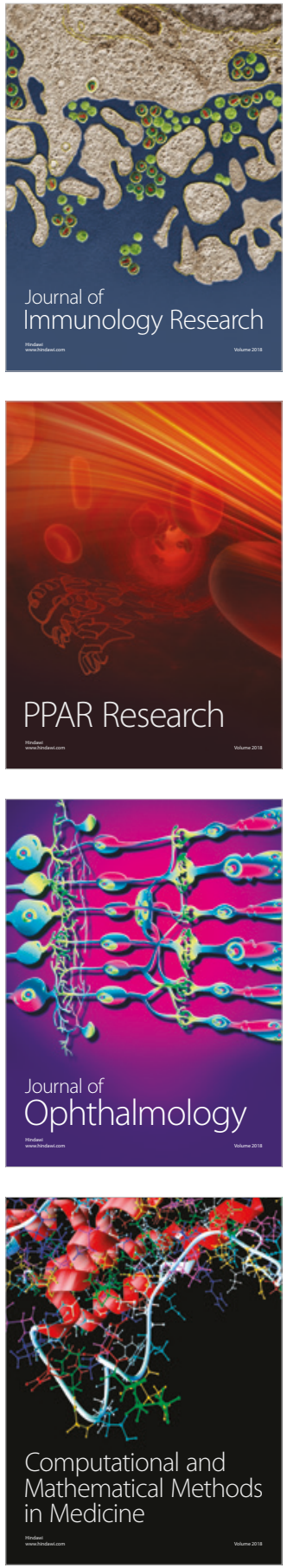

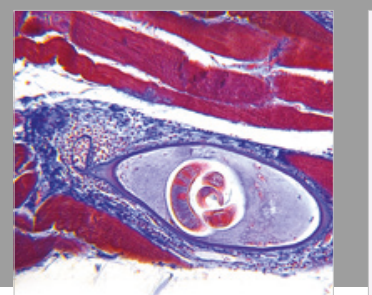

Gastroenterology Research and Practice

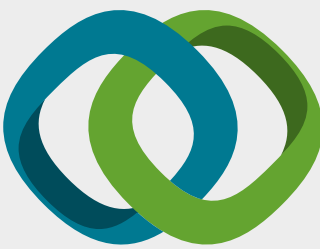

\section{Hindawi}

Submit your manuscripts at

www.hindawi.com
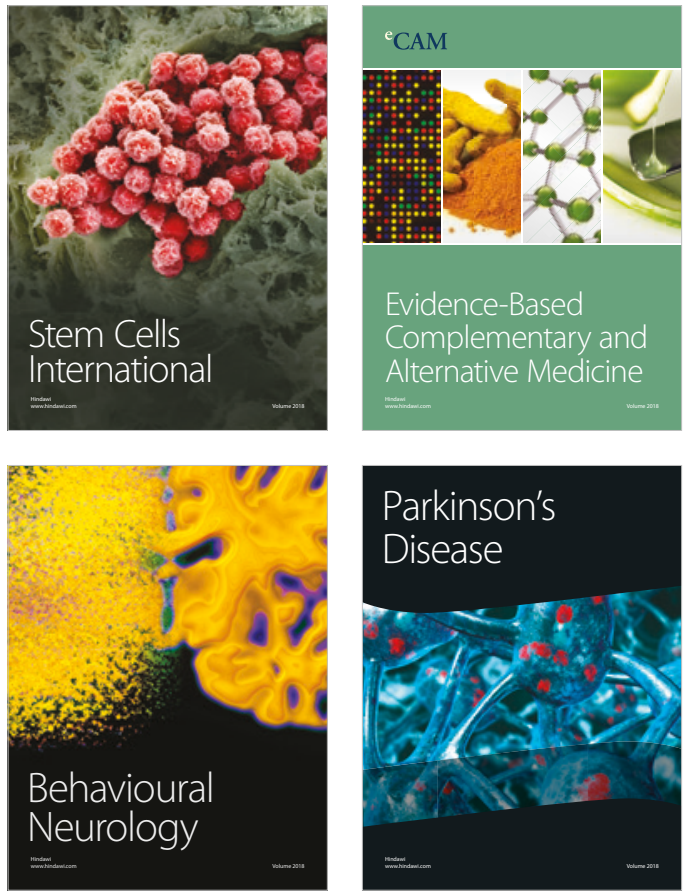

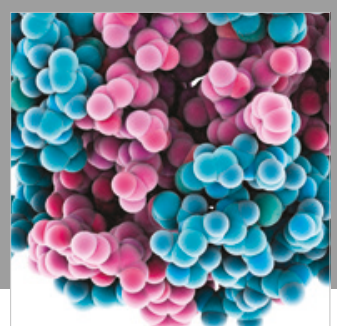

ournal of

Diabetes Research

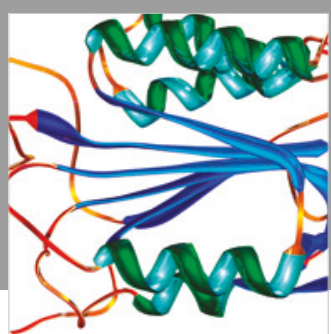

Disease Markers
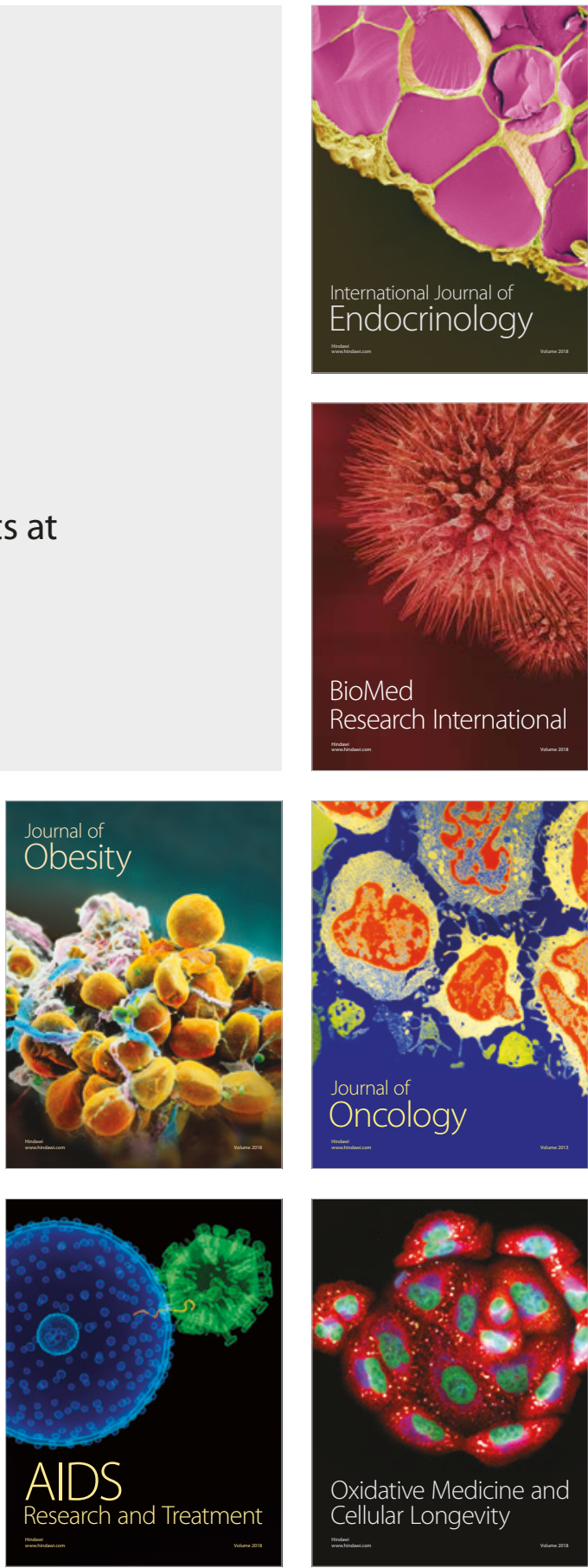